\title{
Moderating role of entrepreneurial orientation on the relationship between entrepreneurial skills, environmental factors and entrepreneurial intention: A PLS approach
}

\author{
Najafi Auwalu Ibrahim ${ }^{a^{*}}$ and Abdulsalam Mas'ud ${ }^{\mathrm{b}}$
}

${ }^{a}$ Bayero University Kano, Nigeria

${ }^{b}$ Hussaini Adamu Federal Polytechnic, Kazaure - Nigeria

\section{CH R O N I L E \\ A B S T R A C T}

Article history:

Received October 28, 2015

Received in revised format

November 28, 2015

Accepted January 17, 2016

Available online

January 20, 2016

Keywords:

Entrepreneurial intention

Entrepreneurial orientation

Entrepreneurial skill

Environmental factors

\begin{abstract}
For decades, entrepreneurship has become a major concern to both scholars and policymakers because of its significant role in economic and social transformation. This paper modeled the direct effects of entrepreneurial skill, environmental factors and entrepreneurial orientation on entrepreneurial intention as well as the indirect (moderating) effect of entrepreneurial orientation on the relationship of entrepreneurial skill and environmental factors with entrepreneurial intention. Quantitative research design was employed using students' sample. It was found that entrepreneurial skill, environmental factors and entrepreneurial orientation have a positive influence on entrepreneurial intention. It was also discovered that entrepreneurial orientation moderates the relationship between entrepreneurial skill and entrepreneurial intention. However, the moderation effect of entrepreneurial orientation on the relationship between environmental factors and entrepreneurial intention was not established in this study, thus, called for exploring this moderating effect in other contexts. As implication to policy, the government should ensure not only enriching students with entrepreneurial skill and conducive entrepreneurial environment but also well-built entrepreneurial orientation among Nigeria teeming youths as it has a direct effect as well as strong interaction with other factors in explaining entrepreneurial intention.
\end{abstract}

\section{Introduction}

For decades, entrepreneurship has become a major concern to both scholars and policy makers because of its significant role in economic and social growth (Brancu et al., 2015). It provides an avenue that drives innovation; create employment that are essential for economic transformation and advancement (Hathaway \& Litan, 2014; Stel \& Suddle, 2008; Wennekers \& Thurik, 1999), thus, government sees it as a panacea of many economic and social vices especially in developing countries (Thornton et al., 2011). These benefits encourage government especially in developing countries to come up with many policies that will enhance entrepreneurship, especially among its teeming youths. Nigeria, being a developing country, has designed a lot of policies to encourage self-reliance primarily to graduate after

* Corresponding author.

E-mail address: najafauwal@gmail.com (N. A. Ibrahim) 
leaving schools, thus, making entrepreneurship studies compulsory to all students in tertiary institutions (Akanbi, 2013). However, the possibility of entrepreneurially trained students to transform into enterpreneurs become a major challenge to the government and scholars (Abidin \& Bakar, 2005; Lucky \& Minai, 2011). In fact, most students and graduates still have their eyes on white collar jobs while adamant to take entrepreneurship as a career despite its numerous advantages (Akanbi, 2013). Consequently, the situation leads to increasing in unemployment as well as poverty rates (Olotu et al., 2015). Thus, the need for understanding the entrepreneurial behavior of these students become a major concern, since its apparent entrepreneurship education alone cannot transform them into venture creation but also intention (Taatila \& Down, 2012). Krueger and Brazeal (1994) posit that individual behavior can be best predict by his intention especially if the behavior is rare and not so easy to observed or predict. In essence, the possibility of engaging in entrepreneurship is more of an individual intention and not education. Also, Shane and Venkataraman (2000) posit that understanding factors that influence one to engage in entrepreneurship are vital research questions need to be answered by entrepreneurship studies. Additionally, studies have identified paucity of research on both individual, entrepreneurial skill and environmental factors in alignment to entrepreneurship intention (Kuzilwa, 2005; Mat \& Razak, 2011; Morales \& Feldman, 2013). Therefore, the present study will investigate the factors that affect student's intention toward engaging entrepreneurial activities. To date, several factors have been identified as the determinants or predictors of entrepreneurial intention; self-efficacy (Boyd \& Vozikis, 1994; Mobaraki \& Zare, 2012), entrepreneurship education (Jorge-Moreno et al., 2012; Solesvik, 2013), personality (Nga \& Shamuganathan, 2010; Zarafshani, 2011) and gender (Gupta \& Turban, 2009; Wilson et al., 2007) to mention a few. However, despite significant number of studies on entrepreneurial intention, there is a paucity of research in the African continent (Fatoki, 2010), developing countries (Drennan \& Saleh, 2008; Nabi \& Liñán, 2011) and specifically within the Nigeria context. Additionally, Schwarz et al. (2009) have called for more studies especially on personal and environmental factors in determining entrepreneurial intention. Furthermore, the dearth in entrepreneurial orientation especially at the individual level is worrisome (Gupta \& Gupta, 2015; Kollmann et al., 2007). Besides Suresh and Ramraj (2012) have also stated that individual characteristics are not enough in determining the entrepreneurial intention of an individual. Moreover, results of most of the studies remain inconclusive or contradictory (Ahl, 2006; Hmielski \& Corbett, 2006), thus the use of a moderating variable (Baron \& Kenny, 1986). Therefore, the present study proposes entrepreneurial orientation as a possible moderator of the relationship between entrepreneurial skill, environmental factors, and entrepreneurial intention. The next part is a literature review, followed by the third part that is methodology. The fourth part is results and discussion, and lastly conclusion and policy implication.

\section{Literature review}

\subsection{Entrepreneurial intention}

Entrepreneurial intention and starting a new business has received a lot of consideration by researchers alike (Krueger \& Carsrud, 1993), normally using the most prominent theory of planned behavior (TPB) (Ajzen, 1991). Therefore, the present study will be underpinned using TBP. The theory clearly explains that intention plays a significant role in determining individual behavior. The TPB explains human behavior using three main factors, subjective norm, attitude and perceived behavioral control. These factors mainly focus on individual behavior that is subjective to his control. Attitude is the extent to which an individual mind accept or reject a specific behavior at a particular point in time, subjective norms is seen as the degree to which individual action is determined by perceived social pressure, perceived behavioral control is strength and willingness of the individual intention towards starting a new business. The duo of Liñán and Santos (2007) posits that intention catches, stimulate, motivate and convert individual's efforts of planning to action. Thus, indicating that performing any behavior

largely depends on the individual intention to exhibit such behavior. The intention has been identified as a major determinant of planned behavior such as entrepreneurial behavior (Ajzen, 1991, 2001; Bird, 1988; Davidsson, 2003; Krueger et al., 2000). Entrepreneurial intention is defined as the mind sets that 
directs, guide, coordinate and control the basic concept (action) of new business development, implementation and evaluation (Bird, 1988). Entrepreneurial intention is also defined as "a state of mind directing a person's attention toward a specific object or a path in order to achieve something" (Vesalainen \& Pihkala, 1999). Similarly, Tubbs and Ekeberg (1991) in their own definition describe that intention as a cognitive of both the objectives, goals and action one is aiming to achieve in accordance with the said objectives. It has been argued that both individual and situational variables play a significant role as predictors of entrepreneurial behavior (Bird, 1988; Lee \& Wong, 2004; Rauch $\&$ Frese, 2000). Thus, leading to many variables been hypothesized within the literature as predictors of new business startup or self-employment (Sánchez, 2011). In essence studies have established a significant relationship with intention and other variables using TPB, for example Sánchez (2011), Drennan and Saleh (2008), Autio et al. (2001) and Díaz-García and Jiménez-Moreno (2010) to mention a few.

\subsection{Entrepreneurial Skills and Entrepreneurial intention}

The need for an entrepreneur to obtain or acquire certain skills for him/her to be successful cannot be over emphasized (Ibrahim \& Lucky, 2014). Skills just like other variables within the social science research lack a generally acceptable definition, however, Wickham (2006) defines skill in a very simple form by referring it as the ability to demonstrate knowledge through action. Similarly, entrepreneurial skill is also defined as the skill in developing or creating a new thing that will add value to the society and generate monetary benefits to the entrepreneur. This skill is as a result of dedication in both tangible and intangible such as time, effort as well as the ability of risk taking in achieving the reality of that idea (Hisrich \& Peters, 2002). Olagunju (2004) posits that the entrepreneurial skill is the individual ability to create a new business through the exploitation of an idea in other to benefit both the individual and the society. In a similar definition by Salgado-banda (2007) identified key factors or characteristics that defined entrepreneurial skill to include "self-belief, boldness, tenacity, passionate, empathy, and readiness" that will motivate and encourage an individual to achieve certain objectives as a result of opportunity and risk taking. Several authors are of the view that for an entrepreneur to be successful, there $\mathrm{a}$ is need for him/her to acquire spacious skills especially business and relationship skills (Lazear, 2004; Michelacci, 2003), as such possessing the needed skill is vital in determining entrepreneurial activity (Boyd \& Vozikis, 1994). However, Lazear (2004) is of the view that entrepreneurs need not be an expert in all skills, but rather what he refers to as "Jack-of-all-trades (JAT)". By this, entrepreneurs are expected to have a balanced skills to successfully run their business as supported by (Wagner, 2003, 2006). Numerous studies such as (Fini, Grimaldi, Marzocchi, \& Sobrero, 2009; Liñán, 2008; Phelan \& Sharpley, 2012; Pyysiainen et al., 2006) have established a significant relationship between entrepreneurial skill and entrepreneurial intention. Thus, the present study hypothesized that:

$\mathrm{H}_{1}$ : Entrepreneurial skill will be positively related to entrepreneurial intention

\subsection{Environmental factor and Entrepreneurial intention}

The reaction of the environment is felt by both entrepreneurs and business, since none of them exist in a vacuum (Peters et al., 1982). Thus, highlighting the complexity of the entrepreneurship concept that involves both individual and the environment in which it occurs (Begley \& Boyd, 1987), explaining the one possible reasons for the differing activities among countries and individuals (Grundstén, 2004). Environment has been identified as critical for entrepreneurial development and its sustainability within a particular country or region (Gnyawali \& Fogel, 1994). In fact, Despite the role of an individual in starting a new venture, environmental factors have been identified as vital in entrepreneurship (Mazzarol et al., 1999), as such need to be fully understood. Furthermore, authors have fully established that new venture only becomes possible as a result of the interaction that exists between environmental factors, personal characteristics and entrepreneurial behavior (Bird, 1988; Greenberg \& Sexton, 1988; Stevenson \& Jarillo, 1990; Suresh \& Ramraj, 2012). In essence, Studies have empirically proved that environmental factors affect entrepreneurial process, thus the existence differences in terms of creation 
of new business, survival and growth (Geissler et al., 2012; Indarti et al., 2010; Kuzilwa, 2005; Maina, 2011; Mat \& Razak, 2011; Román, Congregado, \& Millán, 2013; Shastri \& Sinha, 2010; Uddin \& Bose, 2012). We therefore, hypothesized that:

$\mathrm{H}_{2}$ : Environmental factors will be positively related to entrepreneurial intention.

\subsection{Entrepreneurial orientation will positively moderate entrepreneurial skill and environmental factors}

Entrepreneurial orientation (EO) is an important determinant of entrepreneurial intention that differentiates entrepreneurs and non-entrepreneurs because of their risk-taking, innovativeness and proactiveness ability (Okhomina, 2010; Rauch \& Frese, 2007). This definition is in line with Miller's (1983) conceptualization of the entrepreneurial orientation concept, identifying three basic components that include risk-taking, innovativeness and proactiveness. Moreover, the duo of Lumpkin and Dess (1996) relying on the three identified by Miller also incorporate another two important characteristics of autonomy and competitive aggressiveness. Conversely, studies have argued that proactiveness is more or less same with competitive aggressiveness (Okhomina, 2010; Venkatraman, 1989). Recently, Langkamp Bolton and Lane (2012) classified entrepreneurial orientation concept as a psychological construct that helps in explaining the basic means of understanding the rationale behind individual behaviors toward engaging in entrepreneurial activities. Studies have also found a significant relationship between individual entrepreneurial orientation and entrepreneurial intention as well as business performance (Kollmann et al., 2007; Langkamp Bolton \& Lane, 2012).

In addition to the direct relationship that exist between entrepreneurial orientation and intention, the study also proposed that entrepreneurial orientation will moderate the relationships that exists among entrepreneurial skills, environmental factors and entrepreneurial intention in line with findings that the basic components of entrepreneurial orientation like proactiveness helps in discovering and exploiting the environment toward opportunities identification better than its competitors (Smith \& Cao, 2007). Furthermore, innovativeness played a significant role in the enhancement of abilities in coping with the environment towards innovating new product and services (Ireland, Covin, \& Kuratko, 2009; Jabeen $\&$ Alekam, 2013). Globally they are more than $56 \%$ of people having the needed skills and knowledge to engage in entrepreneurial activities of starting a new business, but only $16.6 \%$ have the intention of starting a new venture or business (Dehghanpour Farashah, 2015). This is to say, that with both entrepreneurial skills and supportive environment one is not likely to engage in any entrepreneurial activities as long as he lacks the basic component of the entrepreneurial orientation of risk-taking, innovativeness and proactiveness to fully scan the environment in order to put his skill in to action that will result in entrepreneurial intention. Similarly, studies have reported mixed findings in the relationship between both entrepreneurial skills and environmental factors with entrepreneurial intention and business performance. For example the likes of (Cant \& Abdullah, 2009; Indarti et al., 2010; Ringle et al., 2005; Taormina \& Lao, 2007; Uddin \& Bose, 2012) have all established a positive relationship while Ahmed, Aamir and Ijaz (2011) and Lucky and Ibrahim (2015) reported a nonsignificant relationship between environment and entrepreneurial intention. In respect to entrepreneurial skills and entrepreneurial intention studies like Sookhtanlo (2009), Liñán (2008) and Fini et al. (2009) reported the existence of a significant relationship unlike Oosterbeek, van Praag and Ijsselstein (2010) that reported a non-significant relationship. The present study, therefore, proposed that:

$\mathrm{H}_{3}$ : Entrepreneurial orientation will be positively related to entrepreneurial intention

$\mathrm{H}_{4}$ : Entrepreneurial orientation will moderate the relationship between entrepreneurial skills and entrepreneurial intention. Specifically, the relationship will be weaker for individuals with lower entrepreneurial orientation than the individual with higher entrepreneurial orientation. 
$\mathrm{H}_{5}$ : Entrepreneurial orientation will moderate the relationship between environmental factors and entrepreneurial intention. Specifically, the relationship will be weaker for individuals with lower entrepreneurial orientation than the individual with higher entrepreneurial orientation.

\section{Methodology}

\subsection{Sample's Description Statistics}

The study utilized a cross-section approach. Respondents were Nigerian students from the eminent management university, University Utara Malaysia, Sintok Kedah Malaysia. Data was generated through convenient random sampling from 200 students drawn across all faculties and level of education. The researchers received 155 out of the 200 distributed questionnaire representing 75.5\%. The descriptive shows that $81.9 \%$ male and $28 \%$ female participated in the study, with 56 ranges between the age of 20-30, 62 between the age of 31-40 and 37 falls between the age of 41 and above. The result further indicates that $31.6 \%, 66.5 \%$, and $1.9 \%$ were single, married and divorced respectively. The academic qualification of the respondents shows that $70.3 \%$ were master's students and $28 \%$ were undergraduate while $1.9 \%$ were Ph.Ds. students.

\subsection{Instrumentation}

The questionnaire contained five sections covering demographic, the three independent variables and the dependent variable. The items were measured using five-point Likert scale with 1 representing "strongly disagree" and 5 representing "strongly agree" aimed at measuring the perception of the respondents towards the variables of the study. All the items used in the study were adapted from previous studies. Entrepreneurial skills and environmental factors items were adapted from (Liñán, 2008), entrepreneurial orientation originated from (Langkamp Bolton \& Lane, 2012) and entrepreneurial intention adapted from (Liñán \& Chen, 2009) respectively.

\subsection{Data Analysis Technique}

The study employed the SmartPLS 2.0 in other to compute the two basic model of PLS path modeling i.e. measurement model and structural model (Anderson \& Gerbing, 1988). Some of the reasons for the use of PLS are: places a very flexible restriction in respect distribution and population of the study (Haenlein \& Kaplan, 2004) and also has the possibility of providing a more reliable and accurate computations of moderating effect because its accounts for error that is capable of reducing the possible relationship as well as the improvement of the validation of the theory (Helm, Eggert, \& Garnefeld, 2010; Henseler \& Fassott, 2010).

\section{Results and discussions}

\subsection{Measurement model results}

A confirmatory factor analysis (CFA) was carried out in order to confirm the reliability of the items, its convergent validity as well as its discriminant validity. Table 1 and 2 shows the items loadings are above the critical threshold of $\geq .50$ as suggested by (Anderson \& Gerbing, 1988; Bagozzi, Yi, \& Phillips, 1991; Gefen \& Straub, 2000). The internal consistency reliability was also achieved using composite reliability, the values were more than the required cut-off value of $\geq .70$ (Bagozzi et al., 1991; Chin, 1998; Hair et al., 2006). Additionally, the convergent validity was also achieved as average variance extracted (AVE) met the minimum criteria of $\geq .5$, its values range between 0.563 to 0.653 (Fornell \& Larcker, 1981; Henseler et al., 2009). As for the discriminant validity (see Table 3) was also achieved as the square root of the AVE were higher than the inter-correlation of each of the study's construct in relation to other constructs of the research model (Chin, 2010; Komiak \& Benbasat, 2006) and also higher than the construct correlations (Chin, 2010). It is fair to say that the measurement model 
satisfactory met both internal consistency reliability, convergent and discriminant validity. Thus, are valid and reliable for further analyses.

Table 1

Cross loadings

\begin{tabular}{|c|c|c|c|c|}
\hline Constructs & $\begin{array}{c}\text { Environ. } \\
\text { Factors }\end{array}$ & Entre. Intention & Entrepreneurial orientation & $\begin{array}{c}\text { Entrepreneuria } \\
\text { Skills }\end{array}$ \\
\hline \multirow{7}{*}{ Environmental Factors } & 0.7199 & 0.1012 & 0.0312 & 0.0947 \\
\hline & 0.8175 & 0.1166 & -0.0358 & 0.185 \\
\hline & 0.8461 & 0.1364 & 0.1126 & 0.2537 \\
\hline & 0.8282 & 0.1407 & 0.1071 & 0.1305 \\
\hline & 0.8141 & 0.0063 & 0.034 & 0.1146 \\
\hline & 0.7896 & 0.0278 & 0.0503 & 0.1464 \\
\hline & 0.8353 & 0.1408 & 0.1308 & 0.2426 \\
\hline \multirow{6}{*}{ Entrepreneurial Intention } & 0.1197 & 0.6995 & 0.3184 & 0.3711 \\
\hline & 0.1494 & 0.8038 & 0.4446 & 0.4248 \\
\hline & 0.1504 & 0.8345 & 0.4724 & 0.3809 \\
\hline & 0.0968 & 0.8649 & 0.4773 & 0.3686 \\
\hline & 0.0676 & 0.7275 & 0.3543 & 0.2888 \\
\hline & 0.1217 & $\mathbf{0 . 7 5 3}$ & 0.3717 & 0.2527 \\
\hline \multirow{3}{*}{ Entrepreneurial orientation } & 0.031 & 0.3106 & 0.6959 & 0.1926 \\
\hline & 0.0741 & 0.3469 & 0.7057 & 0.2451 \\
\hline & 0.0906 & 0.5007 & 0.8551 & 0.3474 \\
\hline \multirow{3}{*}{ Entrepreneurial Skills } & 0.1372 & 0.2487 & 0.2695 & 0.7159 \\
\hline & 0.0449 & 0.3723 & 0.3364 & 0.8075 \\
\hline & 0.3199 & 0.3664 & 0.2034 & 0.7241 \\
\hline
\end{tabular}

Table 2

Item Loading, Internal Consistency, and Average Variance Extracted

\begin{tabular}{|c|c|c|c|c|}
\hline Constructs & Indicators & Loadings & Composite Reliability & AVE \\
\hline \multirow{7}{*}{ Environmental Factors } & EF1 & 0.7199 & 0.929 & 0.653 \\
\hline & EF2 & 0.8175 & & \\
\hline & EF3 & 0.8461 & & \\
\hline & EF4 & 0.8282 & & \\
\hline & EF5 & 0.8141 & & \\
\hline & EF6 & 0.7896 & & \\
\hline & EF7 & 0.8353 & & \\
\hline \multirow{6}{*}{ Entrepreneurial Intention } & EI1 & 0.6995 & 0.904 & 0.613 \\
\hline & EI2 & 0.8038 & & \\
\hline & $\mathrm{EI} 3$ & 0.8345 & & \\
\hline & EI4 & 0.8649 & & \\
\hline & EI5 & 0.7275 & & \\
\hline & EI6 & 0.7530 & & \\
\hline \multirow{3}{*}{ Entrepreneurial Skills } & ES1 & 0.7159 & & \\
\hline & ES3 & 0.8075 & 0.794 & 0.563 \\
\hline & ES5 & 0.7241 & & \\
\hline \multirow{3}{*}{ Entrepreneurial Orientation } & EO10 & 0.6959 & 0.798 & 0.571 \\
\hline & EO8 & 0.7057 & & \\
\hline & EO9 & 0.8551 & & \\
\hline
\end{tabular}

Table 3

Discriminant Validity

\begin{tabular}{lcccc}
\hline Variables & EF & EI & EO & ES \\
\hline EF & $\mathbf{0 . 8 0 8}$ & & & \\
EI & 0.152 & $\mathbf{0 . 7 8 3}$ & & $\mathbf{0 . 7 5 6}$ \\
EO & 0.091 & 0.526 & 0.359 & $\mathbf{0 . 7 5 0}$ \\
\hline ES & 0.226 & 0.450 & & \\
\hline
\end{tabular}

\subsection{Structural Model Results (PLS Path with moderator)}

Hair Jr et al. (2013) posited that there are four key criteria for assessing the structural model in PLSSEM. These include assessments of: (1) significance of the path coefficients, (2) coefficient determination $\left(R^{2}\right),(3)$ the effect size $\left(f^{2}\right)$, and lastly (4) predictive relevance $\left(Q^{2}\right)$. The results for the assessment of the significance of path coefficients are presented in Fig, 2 and Table 4 respectively. 


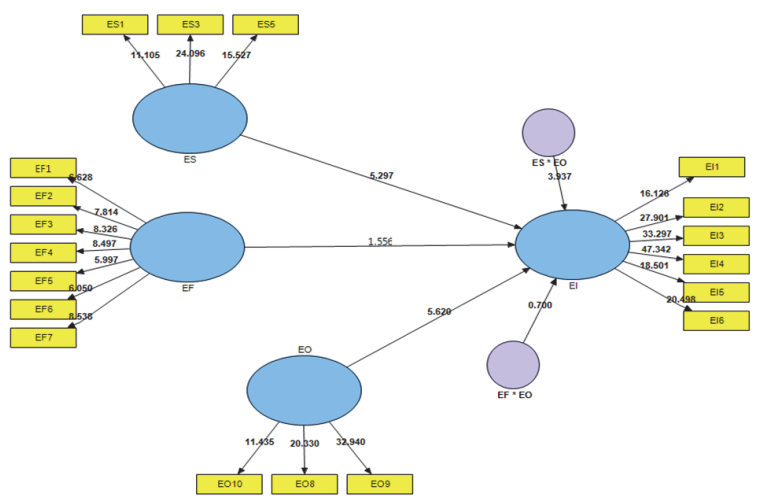

Fig. 1. Structural Model

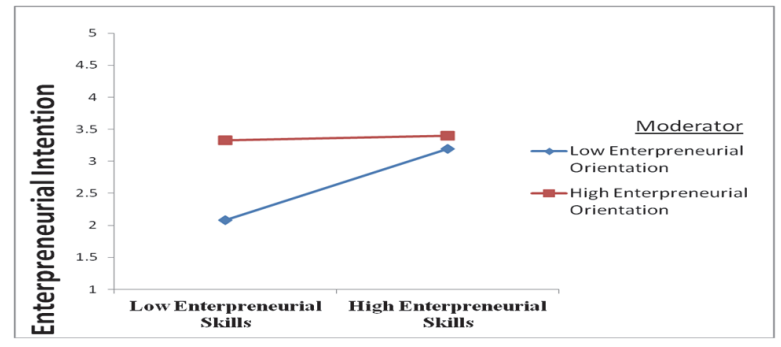

Fig. 2. Interaction effects

The structural model in Fig. 1 presented a path model with three direct effects (ES -> EI; EF-> EI, and EO -> $\mathrm{EI})$ and two indirect (moderating) effects (EF*EO -> EI and ES*EO $->\mathrm{EI})$ respectively. Evaluation of structural path model is presented in Table 4.

Table 4

Path Coefficients for Hypotheses Testing

\begin{tabular}{clllll}
\hline Hypothesis & Beta & Standard Error & T- Statistics & P-Value & Decision \\
\hline ES -> EI & 0.2932 & 0.0553 & 5.2974 & $0.00^{* *}$ & Accepted \\
EF - EI & 0.0841 & 0.054 & 1.5559 & $0.06^{*}$ & Accepted \\
EO -> EI & 0.3616 & 0.0644 & 5.6199 & $0.00^{* *}$ & Accepted \\
ES * EO -> EI & -0.26 & 0.066 & 3.9366 & $0.00^{* *}$ & Accepted \\
EF * EO - > EI & 0.0963 & 0.1377 & 0.6995 & 0.24 & Rejected \\
\hline
\end{tabular}

$* * \mathrm{p}<0.01, * \mathrm{p}<0.1$

The study examines the moderating role of entrepreneurial orientation on the relationship between entrepreneurial skills, environmental factors and entrepreneurial intention. The interpretation and summary of the result are presented in Table 4 . The result indicated that a positive relationship exists between entrepreneurial skill with the entrepreneurial intention of Nigerian students $(\beta=0.29 ; t=5.297$; $p=0.00$ ), thereby supporting H1. The finding of this study is consistent with previous studies (Fini et al., 2009; Liñán, 2008; Phelan \& Sharpley, 2012; Pyysiainen et al., 2006). The result also revealed that a positive relationship exists between environmental factors with entrepreneurial intention of Nigerian students $(\beta=0.84 ; t=1.556 ; p=0.06)$. Hence, $\mathrm{H} 2$ also supported. The result of $\mathrm{H} 2$ is congruent with previous studies (Geissler et al., 2012; Indarti et al., 2010; Kuzilwa, 2005; Maina, 2011; Mat \& Razak, 2011; Román et al., 2013; Shastri \& Sinha, 2010; Uddin \& Bose, 2012). Additionally, the study found a significant and positive relation between entrepreneurial orientation and entrepreneurial intention $(\beta$ $=0.36 ; t=5.620 ; p=0.00$ ) revealing strong support for $\mathrm{H} 3$. The finding with regards to $\mathrm{H} 3$ is in line with prior literature (Cant \& Abdullah, 2009; Indarti et al., 2010; Ringle et al., 2005; Taormina \& Lao, 2007; Uddin \& Bose, 2012). The moderating result shows that entrepreneurial orientation moderates the relationship between ES and entrepreneurial intention $(\beta=-0.26 ; t=3.936 ; p=0.00)$, hence H4 also accepted. This is also consistent with our postulation that the relationship will be weaker for individuals with lower entrepreneurial orientation than the individual with higher entrepreneurial orientation as depicted in Fig. 2. The finding of $\mathrm{H} 4$ is pioneering and the major contribution of this study, because the extent literature does not reveal that the indirect (moderating) effect of entrepreneurship orientation has been investigated. Finally, entrepreneurial orientation fails to moderate the relationship between EF and entrepreneurial intention $(\beta=0.96 ; t=0.700, p=0.24)$ thereby rejecting $\mathrm{H} 5$, hence left for future research in other contexts.

Other criteria revealed strong support for the structural model. The coefficient determination $\left(\mathrm{R}^{2}\right)$ of the model is 0.357 which implied that ES, EF and EO collectively explained $35.7 \%$ of the changes or variations in entrepreneurial intention among Nigerian students. Chin (1998) classified the R-squared 
of $.19, .33$ and .67 as weak, moderate and substantial respectively. Thus, the $\mathrm{R}^{2}$ in this study can be classified as moderate. Another, criterion for evaluating a structural model is effect-size $\left(f^{2}\right)$. Cohen (1988) classified effect-size of $0.02,0.15$ and 0.35 as small, medium, large respectively. The effect sizes $\left(f^{2}\right)$ of the entrepreneurial skills, environmental factors are 0.1073 and 0.0031 which are small effect and no effect respectively. Interestingly, the effect-size $\left(f^{2}\right)$ of the moderator is 0.2286 which higher than that of independent variables can be classified as medium. The last evaluation criterion for the structural model is predictive relevance $\left(Q^{2}\right)$. It is evaluated using construct-cross validated redundancy. Thus, when $\left(Q^{2}\right)$ is greater than zero, the model is said to have predictive relevance (Geisser, 1974; Stone, 1974). With $\left(Q^{2}\right)$ of .2366 which is greater than zero, the model of this study can be said to have predictive relevance.

\section{Conclusion and policy recommendation}

The study examines the direct effect of entrepreneurial skills, environmental factors and entrepreneurial orientation on entrepreneurial intention. It also examined the moderating role of entrepreneurial orientation on the relationship between entrepreneurial skills, environmental factors and entrepreneurial intention. The findings revealed that entrepreneurial skills, environmental factors and entrepreneurial orientation are positively related to entrepreneurial intention. It also revealed that entrepreneurial orientation moderates the relationship between entrepreneurial skills and entrepreneurial intention. However, the moderating effect of entrepreneurial orientation on the relationship between environmental factors and entrepreneurial intention had not been established in this study. Thus, the study recommends the exploration of entrepreneurial orientation as a moderator in other contexts especially in studies where TRA and TPB serve as underpinning theories. The study contributed to the TRA and TPB by integrating the moderating effect entrepreneurial orientation which to the best of the researchers' knowledge has not been studied in the extant literature. The policy implication of the study is an emphasis on entrepreneurial orientation in youth empowerment policies in Nigeria. This recommendation is for two reasons. First, the findings revealed that entrepreneurial orientation not only has a direct influence on entrepreneurial intention but also it interacts strongly with other constructs such as entrepreneurial skills in explaining entrepreneurial intention. Second, within the model presented in this study entrepreneurial orientation which serves as a moderator has the highest effect size on entrepreneurial intention, depicting its relevance for policy formulation. The findings call for National Orientation Agency (NOA) of Nigeria to emphasize more on entrepreneurial orientation in order to realize the potentials possessed by the teeming Nigerian students with regards to entrepreneurial intention.

\section{References}

Abidin, F. Z., \& Bakar, H. (2005). Entrepreneurship education: The case of Universiti Utara Malaysia. Sintok: UUM.

Ahl, H. (2006). Why research on women entrepreneurs needs new directions. Entrepreneurship Theory and Practice, 30(5), 595-621.

Ahmed, I., Aamir, M., \& Ijaz, H. A. (2011). External factors and entrepreneurial career intentions; moderating role of personality traits. International Journal of Academic Research, 3(5).

Icek, A. (1991). The Theory of Planned Behavior, Organizational Behavior and Human Decision Processes, Vol. 50. University of Massachusetts, Amherst.

Ajzen, I. (2001). Nature and operation of attitudes. Annual review of psychology, 52(1), 27-58.

Akanbi, S. T. Familial factors, personality traits and self-efficacy as determinants of entrepreneurial intention among vocational based college of education students in Oyo State, Nigeria.

Anderson, J. C., \& Gerbing, D. W. (1988). Structural equation modeling in practice: A review and recommended two-step approach. Psychological bulletin, 103(3), 411.

Autio, E., H. Keeley, R., Klofsten, M., GC Parker, G., \& Hay, M. (2001). Entrepreneurial intent among students in Scandinavia and in the USA. Enterprise and Innovation Management Studies, 2(2), 145-160.

Bagozzi, R. P., Yi, Y., \& Phillips, L. W. (1991). Assessing construct validity in organizational research. Administrative science quarterly, 421-458. 
Baron, R. M., \& Kenny, D. A. (1986). The moderator-mediator variable distinction in social psychological research: Conceptual, strategic, and statistical considerations. Journal of personality and social psychology, 51(6), 1173.

Begley, T. M., \& Boyd, D. P. (1987). A comparison of entrepreneurs and managers of small business firms. Journal of management, 13(1), 99-108.

Bird, B. (1988). Implementing entrepreneurial ideas: The case for intention. Academy of management Review, 13(3), 442-453.

Boyd, N. G., \& Vozikis, G. S. (1994). The influence of self-efficacy on the development of entrepreneurial intentions and actions. Entrepreneurship theory and practice, 18, 63-63.

Brancu, L., Guðmundsdóttir, S., Gligor, D., \& Munteanu, V. (2015). Is Culture a Moderator of Entrepreneurship Motivation? A Comparative Study of Romania and Iceland. The AMFITEATRU ECONOMIC journal, 38(17).

Abdullah, F., Hamali, J., Rahman Deen, A., Saban, G., \& Zainoren Abg Abdurahman, A. (2009). Developing a framework of success of Bumiputera entrepreneurs. Journal of Enterprising Communities: People and Places in the Global Economy, 3(1), 8-24.

Chin, W. W. (1998). The partial least squares approach to structural equation modeling. Modern methods for business research, 295(2), 295-336.

Chin, W. W. (2010). How to write up and report PLS analyses. In Handbook of partial least squares (pp. 655690). Springer Berlin Heidelberg.

Cohen, J. (1998). Statistical power analysis for the behavioral sciences. Academic press.

Davidsson, P. (2003). The domain of entrepreneurship research: Some suggestions. Advances in entrepreneurship, firm emergence and growth, 6(3), 315-372.

Farashah, A. D. (2015). The effects of demographic, cognitive and institutional factors on development of entrepreneurial intention: Toward a socio-cognitive model of entrepreneurial career. Journal of International Entrepreneurship, 1-25.

Díaz-García, M. C., \& Jiménez-Moreno, J. (2010). Entrepreneurial intention: the role of gender. International Entrepreneurship and Management Journal, 6(3), 261-283.

Drennan, J., \& Saleh, M. (2008). Dynamics of entrepreneurship intentions of MBA students: An Asian developing country perspective. Working paper. Brisbane, Australia: Queensland University of Technology.

Fatoki, O. O. (2010). Graduate entrepreneurial intention in South Africa: motivations and obstacles. International Journal of Business and Management, 5(9), p87.

Fini, R., Grimaldi, R., Marzocchi, G. L., \& Sobrero, M. (2009, June). The foundation of entrepreneurial intention. In Summer Conference (pp. 17-19).

Fornell, C., \& Larcker, D. F. (1981). Evaluating structural equation models with unobservable variables and measurement error. Journal of marketing research, 39-50.

Gefen, D., \& Straub, D. W. (2000). The relative importance of perceived ease of use in IS adoption: a study of e-commerce adoption. Journal of the Association for Information Systems, 1(1), 8.

Geisser, S. (1974). A predictive approach to the random effect model. Biometrika, 61(1), 101-107.

Geissler, M., Jahn, S., Loebel, H., \& Zanger, C. (2011, January). From business opportunity to action: What lies in between? In ICSB World Conference Proceedings (p. 1). International Council for Small business (ICSB).

Gnyawali, D. R., \& Fogel, D. S. (1994). Environments for entrepreneurship development: key dimensions and research implications. Entrepreneurship Theory and Practice, 18, 43-43.

Greenberger, D. B., \& Sexton, D. L. (1988). An interactive model of new venture initiation. Journal of Small Business Management, 26(3), 1-7.

Grundstén, H. (2004). Entrepreneurial intentions and the entrepreneurial environment (Doctoral dissertation, Helsinki University of Technology).

Gupta, V., \& Gupta, A. (2015). The concept of entrepreneurial orientation. Foundations and Trends in Entrepreneurship, 11(2), 55-117.

Gupta, V. K., Turban, D. B., Wasti, S. A., \& Sikdar, A. (2009). The role of gender stereotypes in perceptions of entrepreneurs and intentions to become an entrepreneur. Entrepreneurship theory and practice, 33(2), 397 417.

Haenlein, M., \& Kaplan, A. M. (2004). A beginner's guide to partial least squares analysis. Understanding statistics, 3(4), 283-297.

Hair, J. F., Black, W. C., Babin, B. J., Anderson, R. E., \& Tatham, R. L. (2006). Multivariate data analysis (Vol. 6). Upper Saddle River, NJ: Pearson Prentice Hall.

Hair Jr, J. F., Hult, G. T. M., Ringle, C., \& Sarstedt, M. (2013). A primer on partial least squares structural equation modeling (PLS-SEM). Sage Publications. 
Hathaway, I., \& Litan, R. E. (2014). Declining business dynamism in the United States: A look at states and metros. Brookings Institution.

Helm, S., Eggert, A., \& Garnefeld, I. (2010). Modeling the impact of corporate reputation on customer satisfaction and loyalty using partial least squares. In Handbook of partial least squares (pp. 515-534). Springer Berlin Heidelberg.

Henseler, J., \& Fassott, G. (2010). Testing moderating effects in PLS path models: An illustration of available procedures. In Handbook of partial least squares (pp. 713-735). Springer Berlin Heidelberg.

Henseler, J., Ringle, C. M., \& Sinkovics, R. R. (2009). The use of partial least squares path modeling in international marketing. Advances in International Marketing (AIM), 20, 277-320.

Hisrich, R. D., \& Peters, M. P. (2002). Entrepreneurship, McGraw-Hill.

Hmielski, K. M., \& Corbett, A. C. (2006). Proclivity for improvisation as a predictor of entrepreneurial intentions. Journal of Small Business Management, 44(1), 45.

Ibrahim, N. A., \& Lucky, E. O. I. (2014). Relationship between Entrepreneurial Orientation, Entrepreneurial Skills, Environmental Factor and Entrepreneurial Intention among Nigerian Students in UUM. Entrepreneurship and Innovation Management Journal, 2(4), 203-213.

Indarti, N., Rostiani, R., \& Nastiti, T. (2010). Underlying factors of entrepreneurial intentions among Asian students. The South East Asian Journal of Management, 4(2), 143.

Ireland, R. D., Covin, J. G., \& Kuratko, D. F. (2009). Conceptualizing corporate entrepreneurship strategy. Entrepreneurship Theory and Practice, 33(1), 19-46.

Jabeen, R., Alekam, J. M. E., Aldaoud, K. A. M., Mat, N. K. N., Zureigat, B. N. I., Nahi, A. K., \& al Junaidi, A. M. F. (2013). Antecedents of Firm's Performance. Empirical Evidence from Yemeni Sme's. American Journal of Economics, 3(1), 18-22.

Kollmann, T., Christofor, J., \& Kuckertz, A. (2007). Explaining individual entrepreneurial orientation: Conceptualisation of a cross-cultural research framework. International Journal of Entrepreneurship and Small Business, 4(3), 325-340.

Komiak, S. Y., \& Benbasat, I. (2006). The effects of personalization and familiarity on trust and adoption of recommendation agents. Mis Quarterly, 941-960.

Krueger, N. F., \& Brazeal, D. V. (1994). Entrepreneurial potential and potential entrepreneurs. Entrepreneurship theory and practice, 18, 91-91.

Krueger, N. F., \& Carsrud, A. L. (1993). Entrepreneurial intentions: applying the theory of planned behaviour. Entrepreneurship \& Regional Development, 5(4), 315-330.

Krueger, N. F., Reilly, M. D., \& Carsrud, A. L. (2000). Competing models of entrepreneurial intentions. Journal of business venturing, 15(5), 411-432.

Kuzilwa, J. A. (2005). The Role of Credit for Small Business Success A Study of the National Entrepreneurship Development Fund in Tanzania. Journal of entrepreneurship, 14(2), 131-161.

Langkamp Bolton, D., \& Lane, M. D. (2012). Individual entrepreneurial orientation: Development of a measurement instrument. Education+ Training, 54(2/3), 219-233.

Lazear, E. P. (2004). Balanced skills and entrepreneurship. American Economic Review, 208-211.

Lee, S. H., \& Wong, P. K. (2004). An exploratory study of technopreneurial intentions: A career anchor perspective. Journal of Business venturing, 19(1), 7-28.

Linan, F. (2008). Skill and value perceptions: how do they affect entrepreneurial intentions? International Entrepreneurship and Management Journal, 4(3), 257-272.

Liñán, F., \& Chen, Y. W. (2009). Development and Cross-Cultural application of a specific instrument to measure entrepreneurial intentions. Entrepreneurship Theory and Practice, 33(3), 593-617.

Lucky, E. O. I., \& Ibrahim, N. A. (2015). Environmental Factors and Entrepreneurial Intention among Nigerian Students in UUM. Sains Humanika, 5(2).

Lucky, I., \& Minai, M. S. (2011). The Entrepreneurial Mind of the Female Graduate-to-be in Northern Malaysia. In The Proceeding at the World Business, Economics and Finance Conference.

Maina, R. W. (2011). Determinants of entrepreneurial intentions among Kenyan college graduates. KCA Journal of Business Management, 3(2).

Ekpe, I., Mat, N., \& Razak, R. C. (2011). Attributes, environment factors and women entrepreneurial activity: A literature review. Asian Social Science, 7(9), p124.

Mazzarol, T., Volery, T., Doss, N., \& Thein, V. (1999). Factors influencing small business start-ups: a comparison with previous research. International Journal of Entrepreneurial Behavior \& Research, 5(2), 4863.

Michelacci, C. (2003). Low Returns in R\&D Due to the Lack of Entrepreneurial Skills*. The Economic Journal, 113(484), 207-225. 
Miller, D. (1983). The correlates of entrepreneurship in three types of firms. Management science, 29(7), 770791.

Mobaraki, M. H., \& Zare, Y. B. (2012). Designing Pattern of Entrepreneurial Self-Efficacy on Entrepreneurial Intention. Information Management and Business Review, 4(8), 428.

Morales, C. E., \& Feldman, P. M. (2013). Entrepreneurial skills, significant differences between Serbian and German entrepreneurs. Journal of CENTRUM Cathedra: The Business and Economics Research Journal, 6(1), 129-141.

Nabi, G., \& Liñán, F. (2011). Graduate entrepreneurship in the developing world: intentions, education and development. Education + training, 53(5), 325-334.

Nga, J. K. H., \& Shamuganathan, G. (2010). The influence of personality traits and demographic factors on social entrepreneurship start up intentions. Journal of Business Ethics, 95(2), 259-282.

Okhomina, D. (2010). Entrepreneurial orientation and psychological traits: the moderating influence of supportive environment. Journal of Behavioral Studies in Business, 2(May), 1-16.

Olagunju, Y. A. (2004). Entrepreneurship and Small Scale Business Enterprise Development in Nigeria. University Press.

Olotu, A., Salami, R., \& Akeremale, I. (2015). Poverty and rate of unemployment in Nigeria. Ijm, 2(1).

Oosterbeek, H., Van Praag, M., \& Ijsselstein, A. (2010). The impact of entrepreneurship education on entrepreneurship skills and motivation. European economic review, 54(3), 442-454.

Peters, T. J., Waterman, R. H., \& Jones, I. (1982). In search of excellence: Lessons from America's best-run companies.

Phelan, C., \& Sharpley, R. (2012). Exploring entrepreneurial skills and competencies in farm tourism. Local Economy, 27(2), 103-118.

Pyysiäinen, J., Anderson, A., McElwee, G., \& Vesala, K. (2006). Developing the entrepreneurial skills of farmers: some myths explored. International Journal of Entrepreneurial Behavior \& Research, 12(1), 21-39.

Rauch, A., \& Frese, M. (2000). Psychological approaches to entrepreneurial success: A general model and an overview of findings. International review of industrial and organizational psychology, 15, 101-142.

Rauch, A., \& Frese, M. (2007). Born to be an entrepreneur? Revisiting the personality approach to entrepreneurship. The psychology of entrepreneurship, 41-65.

Ringle, C. M., Wende, S., \& Will, A. (2005). SmartPLS 2.0 (beta).

Román, C., Congregado, E., \& Millán, J. M. (2013). Start-up incentives: Entrepreneurship policy or active labour market programme? Journal of Business Venturing, 28(1), 151-175.

Salgado-Banda, H. (2007). Entrepreneurship and economic growth: An empirical analysis. Journal of Developmental Entrepreneurship, 12(01), 3-29.

Sánchez, J. C. (2011). University training for entrepreneurial competencies: Its impact on intention of venture creation. International Entrepreneurship and Management Journal, 7(2), 239-254.

Schwarz, E. J., Wdowiak, M. A., Almer-Jarz, D. A., \& Breitenecker, R. J. (2009). The effects of attitudes and perceived environment conditions on students' entrepreneurial intent: An Austrian perspective. Education+ Training, 51(4), 272-291.

Shane, S., \& Venkataraman, S. (2000). The promise of entrepreneurship as a field of research. Academy of management review, 25(1), 217-226.

Shastri, R. K., \& Sinha, A. (2010). The socio-cultural and economic effect on the development of women entrepreneurs (with special reference to India).Asian Journal of Business Management, 2(2), 30-34.

Smith, K. G., \& Cao, Q. (2007). An entrepreneurial perspective on the firm-environment relationship. Strategic Entrepreneurship Journal, 1(3-4), 329-344.

Solesvik, M. Z. (2013). Entrepreneurial motivations and intentions: investigating the role of education major. Education+ Training, 55(3), 253-271.

Sookhtanlo, M., Rezvanfar, A., Hashemi, S. M., \& Karaj, I. (2009). Psychological capabilities affecting agricultural students' entrepreneurship level: a comparative study. Research Journal of Agriculture and Biological Sciences, 5(2), 175-184.

Van Stel, A., \& Suddle, K. (2008). The impact of new firm formation on regional development in the Netherlands. Small Business Economics, 30(1), 31-47.

Stevenson, H. H., \& Jarillo, J. C. (1990). A paradigm of entrepreneurship: Entrepreneurial management. Strategic management journal, 11(5), 17-27.

Stone, M. (1974). Cross-validatory choice and assessment of statistical predictions. Journal of the Royal Statistical Society. Series B (Methodological), 111-147. 
Suresh, J., \& Ramraj, R. (2012). Entrepreneurial ecosystem: case study on the influence of environmental factors on entrepreneurial success. European Journal of Business and Management, 4(16), 95-101.

Taatila, V., \& Down, S. (2012). Measuring entrepreneurial orientation of university students. Education+ Training, 54(8/9), 744-760.

Taormina, R. J., \& Kin-Mei Lao, S. (2007). Measuring Chinese entrepreneurial motivation: Personality and environmental influences. International Journal of Entrepreneurial Behavior \& Research, 13(4), 200-221.

Thornton, P. H., Ribeiro-Soriano, D., \& Urbano, D. (2011). Socio-cultural factors and entrepreneurial activity: An overview. International small business journal, 0266242610391930.

Tubbs, M. E., \& Ekeberg, S. E. (1991). The role of intentions in work motivation: Implications for goal-setting theory and research. Academy of Management Review, 16(1), 180-199.

Uddin, M. R., \& Bose, T. K. (2012). Determinants of entrepreneurial intention of business students in Bangladesh. International Journal of Business and Management, 7(24), p128.

Venkatraman, N. (1989). Strategic orientation of business enterprises: The construct, dimensionality, and measurement. Management science, 35(8), 942-962.

Vesalainen, J., \& Pihkala, T. (1999). Entrepreneurial identity, intentions and the effect of the pushfactor. Academy of Entrepreneurship Journal, 5(2), 1-24.

Wagner, J. (2003). Testing Lazear's jack-of-all-trades view of entrepreneurship with German micro data. Applied Economics Letters, 10(11), 687-689.

Wagner, J. (2006). Are nascent entrepreneurs 'Jacks-of-all-trades'? A test of Lazear's theory of entrepreneurship with German data. Applied Economics, 38(20), 2415-2419.

Wennekers, S., \& Thurik, R. (1999). Linking entrepreneurship and economic growth. Small business economics, 13(1), 27-56.

Wickham, P. A. (2006). Strategic entrepreneurship. Pearson Education.

Wilson, F., Kickul, J., \& Marlino, D. (2007). Gender, entrepreneurial Self-Efficacy, and entrepreneurial career intentions: Implications for entrepreneurship Education1. Entrepreneurship theory and practice, 31(3), 387406.

Zarafshani, K., Sharafi, L., \& Rajabi, S. (2011). Using the Myers-Briggs type indicator (MBTI) in the teaching of entrepreneurial skills. International Journal of Science and Technology Education Research, 2(4), 67-74.

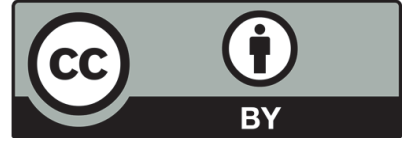

(C) 2016 by the authors; licensee Growing Science, Canada. This article is an open access article distributed under the terms and conditions of the Creative Commons Attribution (CC-BY) license (http://creativecommons.org/licenses/by/4.0/). 